\title{
Latex agglutination, counterimmunoelectrophoresis, and protein A co-agglutination in diagnosis of bacterial meningitis
}

\author{
S. I. S. DIRKS-GO AND H. C. ZANEN
}

From the Department of Bacteriology, the Laboratory of Hygiene, University of Amsterdam, the Netherlands

SUMMARY Specimens of cerebrospinal fluid from 201 patients with meningitis caused by Neisseria meningitidis groups A/B/C/135, Streptococcus pneumoniae (23 types), and Haemophilus influenzae type $\mathrm{b}$ were tested for the presence of specific bacterial antigens by latex agglutination, counterimmunoelectrophoresis (CIE), and protein A co-agglutination. Specific antigens were found in $75 \%$ of the specimens by latex agglutination and $\mathrm{CIE}$, and in $60 \%$ of the specimens by protein $\mathrm{A}$ coagglutination. Non-specific reactions in protein A co-agglutination were prevented by heating the specimens to $100^{\circ} \mathrm{C}$ for a few minutes. The three methods are simple and quick to perform. The smallest amount of antiserum was used in protein A co-agglutination, but we found this method less sensitive. Latex agglutination and CIE proved to be equally sensitive, but the first method was easier to adopt in practice.

The treatment of bacterial meningitis requires a rapid aetiological diagnosis. Gram stain and culture are routine methods but the presence of microorganisms in the Gram stain will not prove the exact cause, and a culture takes 18 hours at least. In the last few years several methods to determine the cause of bacterial meningitis within the shortest possible time have been described (Greenwood et al., 1971; Edwards et al., 1972; Severin, 1972; Whittle et al., 1974; Suksanong and Dajani, 1977). They are all based on the fact that specific bacterial antigens are liberated in the cerebrospinal fluid during the infection, as has been described by Dochez and Avery (1917). In testing 201 specimens from patients with suppurative meningitis caused by meningococci, pneumococci, and Haemophilus influenzae, we compared the three methods: latex agglutination, counterimmunoelectrophoresis (CIE), and protein A co-agglutination.

\section{Material and methods}

\section{SPECIMENS}

We examined 201 specimens of cerebrospinal fluids (CSF) taken from patients suffering from meningitis caused by Neisseria meningitidis (68), Streptococcus pneumoniae (73), or $H$. influenzae type

Received for publication 25 July 1978 b (60). The meningococci belonged to group A (17), group B (33), group C (16), and group 135 (2), and there were 23 types of pneumococci. The specimens were sent to us by a number of bacteriological laboratories in the Netherlands in the course of 1976. Most specimens were sent with isolated microorganisms. When they could not be examined immediately, the specimens were stored at a temperature of $-20^{\circ} \mathrm{C}$. When microorganisms were brought in, they were inoculated again, identified, grouped, and/or typed and freeze-dried, and kept at $-70^{\circ} \mathrm{C}$.

\section{CONTROLS}

The 201 CSF specimens were examined with all antisera that were used to check on specificity. Additionally, we tested one specimen from a patient probably suffering from viral meningitis, two specimens from patients with suppurative meningitis from which microorganisms had not been isolated, and four samples from patients with meningitis caused by Staphylococcus aureus, Streptococcus agalactiae, Escherichia coli, and $H$. influenzae type f.

ANTISERA

Latex agglutination: $N$. meningitidis groups $\mathrm{A} / \mathrm{B} / \mathrm{C} /$ 135 (GZL) ${ }^{1}$, Strep. pneumoniae omniserum ${ }^{1}$ GZL - Gezondheidsleer - The Laboratory of Hygiene, Department of Bacteriology, University of Amsterdam, the Netherlands 
(Statens Seruminstitut), H. influenzae type b (Burro 132-Robbins).

Counterimmunoelectrophoresis: $N$. meningitidis groups $\mathrm{A} / \mathrm{B} / \mathrm{C} / 135$ (GZL), Strep. pneumoniae omni/pool/type-sera (Statens Seruminstitut), $\boldsymbol{H}$. influenzae type b (Burro 132-Robbins), $H$. influenzae type b (Statens Seruminstitut), $H$. influenzae types a-f (Wellcome).

Protein A co-agglutination: $N$. meningitidis groups A/B/C/135 (GZL), Strep. pneumoniae omni/ pool-sera (Statens Seruminstitut), $H$. influenzae type b (Statens Seruminstitut).

We prepared antisera of $N$. meningitidis groups A/B/C/135 (GZL) in our laboratory by the immunisation of rabbits (Severin, 1972). The antisera were tested for specificity by CIE and double gel diffusion (Slaterus, 1961). Nonspecific antisera were absorbed by cross-reacting antigens (Danielsson and Kronvall, 1974). The antiserum $H$. influenzae type b (Burro 132) was a gift from John E. Robbins (Department of Health, Education and Welfare, Bethesda, Maryland, USA).

\section{LATEX AGGLUTINATION TEST}

Polystyrene latex particles $(0 \cdot 81 \mathrm{~m} \mu$, Difco) were sensitised with $\gamma$-globulin by the method described by Severin in 1972. With the exception of Strep. pneumoniae omniserum, $\gamma$-globulin was precipitated with a $50 \%$ saturated ammonium sulphate solution. A slide with hollows (Assistent) was used for the agglutination; $0.005 \mathrm{ml}$ sensitised latex was added to $0.01 \mathrm{ml}$ of specimen and rotated for three minutes at $150 \mathrm{rpm}$ on the electric rotating apparatus (A. H. Thomas Co). The agglutination was then observed immediately with the naked eye.

The latex coated with pneumococcal omniserum showed granular agglutination (Whittle et al., 1974), and we therefore checked each test with a physiological saline solution to prevent incorrect positive interpretation.

COUNTERIMMUNOELECTROPHORESIS

We used $7 \times 7 \mathrm{~cm}$ glass slides with $1 \%$ agarose in a barbital buffer solution (pH 8.6-ionic strength 0.02) according to the method described by Edwards et al. (1972), Greenwood et al. (1971), and Fossieck et al. (1973). A barbital buffer solution with a pH of 8.6 and ionic strength of 0.1 was used in the buffer reservoir of the electrophoresis apparatus. The slides were subjected to a constant 80 volts at room temperature for 30 minutes. The precipitation lines were then observed immediately before the slides were put in $\mathrm{a} 0.02 \%$ thiomersal $\mathrm{NaCl}$ water bath for 18 hours. They were then dried and stained with Coomassie brilliant blue (R250 Merck).
PROTEIN A CO-AGgLUTINATION TEST

The staphylococcal protein A was prepared by the method described by Arvidson et al. (1970) and Kronvall (1973) with minor modifications. Columbia agar plates with a diameter of $14 \mathrm{~cm}$ were used for the culture of Staph. aureus (Cowan I NCTC 8530). The microorganisms were taken off with a glass rod and suspended in PBS pH 7*4. The suspension was treated with $0.5 \%$ formaldehyde and heated, rotating in a water bath at a temperature of $80^{\circ} \mathrm{C}$. We used a $1 \%$ protein A suspension for all antisera at first, but co-agglutination was unsatisfactory with pneumococcal omniserum for which we then used a $2 \%$ protein A suspension. The staphylococcal protein A coated with antiserum was used unwashed (Edwards and Larson, 1974). The CSF specimens were heated to $100^{\circ} \mathrm{C}$ for two minutes and centrifuged. The clear liquid separated at the top was used for co-agglutination on a micro-slide with hollows (Assistent); $0.01 \mathrm{ml}$ of the protein A coated with antiserum was added to $0.01 \mathrm{ml}$ of the clear liquid and rotated for four minutes at $300 \mathrm{rpm}$ on the electric rotating apparatus (A. H. Thomas Co). Co-agglutination was then observed immediately with the naked eye.

IDENTIFICATION OF MICROORGANISMS

N. meningitidis was inoculated on Mueller Hinton $\bigcirc \vec{\ominus}$ agar with $1 \%$ supplement B (Difco), incubated at $37^{\circ} \mathrm{C}$ in a candle jar, and then identified by Gramō stain, oxidation, and fermentation of glucose and maltose on GC medium with indicator.

$N$. meningitidis was grouped by agglutination and microprecipitation of the microorganisms with the group-specific antisera (Slaterus, 1961). For the culture of Strep. pneumoniae, identified by Gram stain and sensitivity to ethylhydrocuprein (Optochin), $5 \%$ horse blood agar was used (Columbia agar base BBL). Pneumococci were grouped by the membrane swelling reaction according to Neufeld.

$H$. influenzae was inoculated on to chocolate agar and identified by Gram stain and growth dependency on $\mathrm{X}$ and $\mathrm{V}$ factors on NAD plates (Evans et al., 1975). $H$. influenzae was typed by co-agglutination with staphylococcal protein A coated with specific antiserum (Kronvall, 1973; Christensen et al., 1973).

\section{Results}

Of 201 CSF specimens from patients with meningitis caused by $N$. meningitidis, Strep. pneumoniae, and $H$. influenzae type $\mathrm{b}$, we found specific antigens with latex agglutination in $151(75.1 \%)$, with CIE in 152 $(75.6 \%)$, and with protein A co-agglutination in 121 $(60.2 \%)$ specimens.

Specification of the positive reactions of each type of microorganism is found in Tables 1,2 , and 3 . 
Table 1 Numbers of specific polysaccharides found in CSF specimens

\begin{tabular}{|c|c|c|c|c|}
\hline \multirow{2}{*}{$\begin{array}{l}\text { Isolated } \\
\text { strains }\end{array}$} & \multirow{2}{*}{$\begin{array}{l}\text { Number of } \\
\text { specimens }\end{array}$} & \multicolumn{3}{|c|}{ Specific polysaccharides found by: } \\
\hline & & $\begin{array}{l}\text { Latex } \\
\text { agglutination }\end{array}$ & CIE & $\begin{array}{l}\text { Protein A } \\
\text { co- } \\
\text { agglutination }\end{array}$ \\
\hline $\begin{array}{l}\text { N. meningi- } \\
\quad \text { tidis } \\
\text { groups } \\
\text { A/B } / C / 135\end{array}$ & $68(100 \%)$ & $48(70 \cdot 6 \%)$ & $50(73 \cdot 5 \%)$ & $33(48 \cdot 5 \%)$ \\
\hline $\begin{array}{l}\text { Strep. } \\
\text { pneumoniae } \\
H . \text { influenzae }\end{array}$ & $73(100 \%)$ & $57(78 \cdot 1 \%)$ & $47(64 \cdot 4 \%)$ & $54(74 \cdot 0 \%)$ \\
\hline type b & $60(100 \%)$ & $46(76.7 \%)$ & $55(91 \cdot 7 \%)$ & $34(56.7 \%)$ \\
\hline Total & $201(100 \%)$ & $151(75.1 \%)$ & $152(75 \cdot 6 \%)$ & $121(60.2 \%)$ \\
\hline
\end{tabular}

Table 2 Numbers of specific meningococcal polysaccharides found in CSF specimens

\begin{tabular}{|c|c|c|c|c|}
\hline \multirow{2}{*}{$\begin{array}{l}\text { Isolated } \\
\text { strains }\end{array}$} & \multirow{2}{*}{$\begin{array}{l}\text { Number of } \\
\text { specimens }\end{array}$} & \multicolumn{3}{|c|}{ Specific polysaccharides found by: } \\
\hline & & $\begin{array}{l}\text { Latex } \\
\text { agglutination }\end{array}$ & CIE & $\begin{array}{l}\text { Protein A } \\
\text { co- } \\
\text { agglutination }\end{array}$ \\
\hline $\begin{array}{l}\text { N. meningi- } \\
\text { tidis } \\
\text { group A } \\
\begin{aligned} & \text { B } \\
& \text { C } \\
& 135\end{aligned}\end{array}$ & $\begin{array}{c}17(100 \%) \\
33(100 \%) \\
16(100 \%) \\
2\end{array}$ & $\begin{array}{l}16(94 \cdot 1 \%) \\
17(51 \cdot 5 \%) \\
13(81 \cdot 3 \%) \\
2\end{array}$ & $\begin{array}{l}16(94.1 \%) \\
20(60.6 \%) \\
12(75.0 \%) \\
2\end{array}$ & $\begin{array}{r}11(64 \cdot 7 \%) \\
9(27 \cdot 3 \%) \\
11(68 \cdot 8 \%) \\
2\end{array}$ \\
\hline Total & $68(100 \%)$ & $48(70 \cdot 6 \%)$ & $50(73 \cdot 5 \%)$ & $33(48 \cdot 5 \%)$ \\
\hline
\end{tabular}

Table 3 Numbers of specific pneumococcal polysaccharides found in CSF specimens

\begin{tabular}{|c|c|c|c|c|}
\hline \multirow{2}{*}{$\begin{array}{l}\text { Isolated } \\
\text { strains }\end{array}$} & \multirow{2}{*}{$\begin{array}{l}\text { Number of } \\
\text { specimens }\end{array}$} & \multicolumn{3}{|c|}{ Specific polysaccharides found by: } \\
\hline & & $\begin{array}{l}\text { Latex } \\
\text { agglutination }\end{array}$ & CIE & $\begin{array}{l}\text { Protein A } \\
\text { co- } \\
\text { agglutination }\end{array}$ \\
\hline
\end{tabular}

\begin{tabular}{|c|c|c|c|c|}
\hline \multicolumn{5}{|c|}{$\begin{array}{l}\text { Strep. } \\
\quad \text { pneumoniae }\end{array}$} \\
\hline Pool A & 19 & 16 & 16 & 17 \\
\hline B & 18 & 15 & 11 & 13 \\
\hline C & 9 & 8 & $4^{*}$ & 8 \\
\hline D & 3 & 2 & 2 & 1 \\
\hline $\mathbf{E}$ & 8 & 4 & 3 & 4 \\
\hline $\mathbf{F}$ & 1 & - & 1 & - \\
\hline C & 3 & 3 & 3 & 3 \\
\hline $\mathbf{H}$ & 12 & 9 & 7 & 8 \\
\hline Total & $73(100 \%)$ & $57(78.1 \%)$ & $47(64 \cdot 4 \%)$ & $54(74.0 \%)$ \\
\hline
\end{tabular}

*Three Strep. pneumoniae type 7 positive after 18 hours water bath.

Latex agglutination is just as sensitive as CIE in the detection of polysaccharides of $N$. meningitidis groups A, C, and 135 (Table 2). Polysaccharides were detected in only $50-60 \%$ of the specimens when meningitis had been caused by meningococci group B.

The results of protein A co-agglutination in the detection of polysaccharides in the case of meningococcal meningitis was only $48.5 \%$. Protein A co- agglutination gave better results than CIE in the detection of Strep. pneumoniae polysaccharides.

When pool-sera or type-sera were used in these two methods, the reaction did not increase in sensitivity (El-Refaie and Dulake, 1975). Polysaccharides of Strep.pneumoniae types 7 and 14 were not detected by CIE; three out of eight Strep. pneumoniae type 7 specimens showed precipitation lines with the antiserum after 18 hours' diffusion in a water-bath. We restricted research into polysaccharides of $H$. influenzae to type b because this type causes $H$. influenzae infections in $95 \%$ of cases (Weinstein, 1970). We used three different antisera (Robbins, Statens Seruminstitut, and Wellcome) to detect the antigens of this microorganism with CIE.

The $H$. influenzae type b antiserum Burro 132 (Robbins) showed a positive reaction in 55 out of 60 specimens $(91.7 \%)$; the same types of antisera from the Statens Seruminstitut and Wellcome showed a similar reaction in 45 out of $60(75.0 \%)$ and in 23 out of $60(38.3 \%)$ specimens respectively. We could not use the Burro 132 antiserum in the co-agglutination test because staphylococcal protein A does not react to the $\gamma$ G-globulins of this species (Grov et al., 1970; Lind et al., 1970).

Four CSF specimens from patients with pneumococcal meningitis showed nonspecific reactions: two specimens in latex agglutination with meningococci group $B$ and two with meningococcal groups $A$ and $C$ antiserum in CIE.

Nonspecific reactions did not occur when the specimens were heated. The CSF specimens from patients with meningitis caused by $H$. influenzae type $f$ reacted only with the type-specific antiserum.

\section{Discussion}

We found scarcely any difference in sensitivity between latex agglutination and CIE for the detection of antigens in the cerebrospinal fluid of patients with meningitis caused by meningococci, pneumococci, and $H$. influenzae type $b$. This confirmed the findings of Whittle et al. (1974) and Leinonen and Herva (1977).

Protein A co-agglutination-used for grouping and typing microorganisms (Christensen et al., 1973; Kronvall, 1973; Olcén et al., 1975)-now proved to be a method for the detection of antigens in cerebrospinal fluid. Contrary to the findings of Suksanong and Dajani (1977), we found that most specimens showed nonspecific reactions with staphylococcal protein A. Olcén et al. (1975) eliminated nonspecific reactions by absorbing the CSF specimens with a pure solution of protein $A$. When we treated the specimens with a pure solution of protein A, they still showed nonspecific reactions, but these 
disappeared when the specimens were heated to $100^{\circ} \mathrm{C}$ for $1-2$ minutes before the test, probably by the coagulation of proteins that had caused the cross reactions. This method proved to be less sensitive for the detection of antigens in the specimens than latex agglutination and CIE, with the exception of pneumococci. At first we believed that heating the specimens caused the reduction in polysaccharide level, but the results of CIE were not influenced by heating. The cause may be found in the antisera that we used. These probably contained insufficient amounts of $\gamma$ G-globulin that could be combined with protein A.

The lowest levels of polysaccharides were found in the specimens of patients with meningococcal group B meningitis, although over $50 \%$ of meningococcal meningitis in the Netherlands is caused by this group (Annual Reports, 1975 and 1976).

Severin (1972) and Leinonen and Herva (1977) found polysaccharides of meningococci groups $\mathbf{A}$ and $C$ in the CSF specimens by latex agglutination but could not find polysaccharides in any of their meningococci group $B$ specimens.

Cheever (1965) believed that the absence of a soluble polysaccharide in this group might be the reason. Maloney et al. (1972) said that after the exponential growing time the meningococci group B polysaccharide quickly decreases in the culture medium, groups $\mathrm{A}$ and $\mathrm{C}$ polysaccharides remaining stable. This is caused by the acid instability of the group B polysaccharide molecule.

When we started work in our laboratory we could not prepare a meningococcal group $B$ antiserum that could be used in latex agglutination, CIE, and protein A co-agglutination. By using strain M2092 (Sara Branham) for the immunisation of rabbits and taking into account the time of growth ( 8 hours) and the freshness of the culture used as a vaccine, we obtained an excellent precipitating and agglutinating antiserum that was suitable for the detection of group B polysaccharide by the three methods.

Polysaccharides of Strep. pneumoniae types 7 and 14 were not found by CIE when the current buffers were used because these polysaccharides are neutral (Anhalt and Yu, 1975; Kenny et al., 1972). This is the reason why test results by CIE were lower than those by the other two methods.

The results of protein A co-agglutination (56.7\% positive) of $\boldsymbol{H}$. influenzae type b cannot be compared to the results of latex agglutination ( $76.7 \%$ positive) and CIE ( $91.7 \%$ positive) because a different antiserum was used for protein A co-agglutination. When the same antiserum was used for CIE and protein A co-agglutination, CIE results were $75 \%$ positive.

For the purpose of the investigation, the three methods compared here proved to be quick and simple to perform. Protein A co-agglutination required a very small quantity of antiserum $\left(1 / 100^{\text {th }}\right.$ of the quantity used in CIE). The sensitivity of protein A co-agglutination was fairly low but would probably be increased by the use of a suitable antiserum. The antiserum combined with protein $A$ will keep for only six months, and this remains a difficulty. Although latex agglutination and CIE are equally sensitive, the former would be preferable as a routine method as it does not require extensive and expensive apparatus.

Other advantages of this method are easy execution of the test and the good keeping qualities, three years at least, of the antiserum combined with latex.

We thank Miss C. Th. P. Hopman for preparing the meningococcal antisera, especially of group B.

\section{References}

Anhalt, J. P., and Yu, P. K. W. (1975). Counterimmunoelectrophoresis of pneumococcal antigens: improved sensitivity for the detection of types VII and XIV. Journal of Clinical Microbiology, 2, 510-515.

Annual reports (1975 and 1976). GZL (The Laboratory of Hygiene, Department of Bacteriology, University of Amsterdam, the Netherlands).

Arvidson, S., Holme, T., and Wadström, T. (1970). Formation of bacteriolytic enzymes in batch and continuous culture of Staphylococcus aureus. Journal of Bacteriology, 104, 227-233.

Cheever, F. S. (1965). The meningococci. In: Bacterial and Mycotic Infections of Man, edited by R. J. Dubos and J. G. Hirsch, 4th edition, p. 443. Lippincott, Philadelphia.

Christensen, P., Kahlmeter, G., Jonsson, S., and Kronvall G. (1973). New method for the serological grouping of streptococci with specific antibodies adsorbed to protein A-containing staphylococci. Infection and Immunity, 7, 881-885.

Danielsson, D., and Kronvall, G. (1974). Slide agglutination method for the serological identification of Neisseria gonorrhoeae with anti-gonococcal antibodies adsorbed to protein A-containing staphylococci. Applied Microbiology, 27, 368-374.

Dochez, A. R., and Avery, O. T. (1917). The elaboration of specific soluble substance by pneumococcus during growth. Journal of Experimental Medicine, 26, 477-493.

Edwards, E. A., Muehl, P. M., and Peckinpaugh, R. O. (1972), Diagnosis of bacterial meningitis by counterimmunoelectrophoresis. Journal of Laboratory and Clinical Medicine, 80, 449-454.

Edwards, E. A., and Larson, G. L. (1974). New method of grouping beta-hemolytic streptococci directly on sheep blood agar plates by coagglutination of specifically sensitized protein A-containing staphylococci. Applied Microbiology, 28, 972-976.

El-Refaie, M., and Dulake, C. (1975). Counter-current 
immunoelectrophoresis for the diagnosis of pneumococcal chest infection. Journal of Clinical Pathology, 28, 801-806.

Evans, N. M., Bell, S. M., and Smith, D. D. (1975). New satellitism test for isolation and identification of Haemophilus influenzae and Haemophilus parainfluenzae in sputum. Journal of Clinical Microbiology, 1, 89-95.

Fossieck, B., Jr., Craig, R., and Paterson, P. Y. (1973). Counterimmunoelectrophoresis for rapid diagnosis of meningitis due to Diplococcus pneumoniae. Journal of Infectious Diseases, 127, 106-109.

Greenwood, B. M., Whittle, H. C., and DominicRajkovic, O. (1971). Counter-current immunoelectrophoresis in the diagnosis of meningococcal infections. Lancet, 2, 519-521.

Grov, A., Oeding, P., Myklestad, B., and Aasen, J. (1970). Reactions of staphylococcal antigens with normal sera, $\gamma \mathrm{G}$-globulins, and $\gamma \mathrm{G}$-globulin fragments of various species origin. Acta Pathologica Microbiologica Scandinavica, 78B, 106-111.

Kenny, G. E., Wentworth, B. B., Beasley, R. P., and Foy, H. M. (1972). Correlation of circulating capsular polysaccharide with bacteremia in pneumococcal pneumonia. Infection and Immunity, 6, 431-437.

Kronvall, G. (1973). A rapid slide-agglutination method for typing pneumococci by means of specific antibody adsorbed to protein A-containing staphylococci. Journal of Medical Microbiology, 6, 187-190.

Leinonen, M., and Herva, E. (1977). The latex agglutination test for the diagnosis of meningococcal and Haemophilus influenzae meningitis. Scandinavian Journal of Infectious Diseases, 9, 187-191.

Lind, I., Live, I., and Mansa, B. (1970). Variation in staphylococcal protein A reactivity with $\gamma \mathrm{G}$-globulins of different species. Acta Pathologica Microbiologica Scandinavica, 78B, 673-682.

Maloney, P. C., Schneider, H., and Brandt, B. L. (1972). Production and degradation of serogroup B Neisseria meningitidis polysaccharide. Infection and Immunity, 6, 657-661.

Olcén, P., Danielsson, D., and Kjellander, J. (1975). The use of protein A-containing staphylococci sensitized with anti-meningococcal antibodies for grouping Neisseria meningitidis and demonstration of meningococcal antigen in cerebrospinal fluid. Acta Pathologica Microbiologica Scandinavica, 83B, 387-396.

Severin, W. P. J. (1972). Latex agglutination in the diagnosis of meningococcal meningitis. Journal of Clinical Pathology, 25, 1079-1082.

Slaterus, K. W. (1961). Serological typing of meningococci by means of micro-precipitation. Antonie van Leeuwenhoek, 27, 305-315.

Suksanong, M., and Dajani, A. S. (1977). Detection of Haemophilus influenzae type B antigens in body fluids, using specific antibody-coated staphylococci. Journal of Clinical Microbiology, 5, 81-85.

Weinstein, L. (1970). Type B Haemophilus influenzae infections in adults. New England Journal of Medicine, 283, 221-222.

Whittle, H. C., Tugwell, P., Egler, L. J., and Greenwood, B. M. (1974). Rapid bacteriological diagnosis of pyogenic meningitis by latex agglutination. Lancet, 2 , 619-621.

Requests for reprints to: Professor H. C. Zanen, Bacteriology Department, Laboratory of Hygiene, University of Amsterdam, Mauritskade 57, Amsterdam-O, the Netherlands. 